\title{
CHEK2 1100DELC GERMLINE MUTATION: a frequency study in hereditary breast and colon cancer Brazilian families
}

\author{
Jamile ABUD ${ }^{1.2}$, Patrícia KOEHLER-SANTOS², Patricia ASHTON-PROLLA ${ }^{2,3,4,5,6}$, \\ João Carlos PROLLA ${ }^{1,7}$ and The Study Group on Hereditary Breast and Colorectal Cancer*
}

\begin{abstract}
Context - CHEK2 encodes a cell cycle checkpoint kinase that plays an important role in the DNA damage repair pathway, activated mainly by ATM (Ataxia Telangiectasia Mutated) in response to double-stranded DNA breaks. A germline mutation in $C H E K 2,1100 \mathrm{delC}$, has been described as a low penetrance allele in a significant number of families with breast and colorectal cancer in certain countries and is also associated with increased risk of contralateral breast cancer in women previously affected by the disease. About $5 \%-10 \%$ of all breast and colorectal cancers are associated with hereditary predisposition and its recognition is of great importance for genetic counseling and cancer risk management. Objectives - Here, we have assessed the frequency of the CHEK2 1100delC mutation in the germline of 59 unrelated Brazilian individuals with clinical criteria for the hereditary breast and colorectal cancer syndrome. Methods - A long-range PCR strategy followed by gene sequencing was used. Results - The 1100delC mutation was encountered in the germline of one (1.7\%) individual in this high risk cohort. This indicates that the CHEK2 1100delC is not commonly encountered in Brazilian families with multiple diagnoses of breast and colorectal cancer. Conclusion - These results should be confirmed in a larger series of families and further testing should be undertaken to investigate the molecular mechanisms underlying the hereditary breast and colorectal cancer phenotype.
\end{abstract}

HEADINGS - Breast neoplasms, genetics. Colonic neoplasms, genetics. Protein-serine-threonine-kinase, genetics. Genetic predisposition to disease.

\section{INTRODUCTION}

The CHEK2 gene (OMIM\#604373, also known as $C H K 2$ ) is the mammalian homologue of the $S a c$ charomyces cerevisiae RAD53 and Schizosaccharomyces pombe Cds1 genes. In humans, it is located in 22q12.1, and encodes a cell cycle checkpoint kinase that is implicated in DNA damage responses ${ }^{(9,19)}$. Following the occurrence of double-stranded DNA breaks, $C H E K 2$ is activated through phosphorylation by $A T M$. Activated $C H E K 2$ then phosphorylates critical cell-cycle proteins, including Cdc25A and Cdc25C phosphatases, P1K3 kinase and the E2F1 transcription factor, as well as proteins involved in DNA repair (such as brca1) and in regulation of cell death (such as p53-mdm2 and pml-1). This reflects the wide mediator role of $C H E K 2$ in the signaling pathways in response to DNA damage, with direct impact on downstream effectors within the cell cycle checkpoints, DNA repair and apoptosis machineries. These findings have been well documented in cells with a functional deficiency of $C H E K 2^{(28,32)}$.

CHEK2 has been considered a candidate tumor suppressor gene, and germline mutations in this gene seem to predispose to familial breast cancer (BC) and other malignancies ${ }^{(2,6)}$. In 1999, germline mutations in CHEK2 were associated with the Li-Fraumeni syndrome (LFS) phenotype ${ }^{(3)}$. However, a strong association with the syndrome and this variant has never been confirmed ${ }^{(30)}$. Also in 1999, Bell et al. ${ }^{(3)}$ described for the first time the 1100delC mutation in exon 10 of CHEK2 in families with breast and/or colorectal cancer, and association with an intermediate relative risk for the occurrence of these tumors has been confirmed in subsequent reports ${ }^{(1,24,42)}$. Meijers-Heijboer et al. ${ }^{(24)}$ in the Netherlands investigated the frequency of CHEK2 $1100 \mathrm{delC}$ in 55 families with multiple breast and colorectal cancer diagnoses and encountered the mutation

\footnotetext{
Declared conflict of interest of all authors: none

1 Programa de Pós-Graduação em Medicina: Ciências Gastroenterológicas, Universidade Federal do Rio Grande do Sul (UFRGS). Porto Alegre, RS, Brasil; ${ }^{2}$ Laboratório de Medicina Genômica, Centro de Pesquisa Experimental, Hospital de Clínicas de Porto Alegre (HCPA), Porto Alegre, RS, Brasil; ${ }^{3}$ Serviço de Genética Médica, HCPA; ${ }^{4}$ Departamento de Genética, UFRGS; ${ }^{5}$ Programa de Pós-Graduação em Genética e Biologia Molecular, UFRGS; ${ }^{6}$ Instituto Nacional de Genética Médica Populacional (INAGEMP), Brasil; ; Departamento de Medicina Interna, UFRGS; ${ }^{7}$ Faculdade de Medicina, UFRGS; ${ }^{9}$ Laboratório de Oncologia Molecular, Hospital de Câncer de Barretos, SP, Brasil; ${ }^{10}$ Instituto Nacional do Câncer (INCA), Rio de Janeiro, RJ, Brasil; ${ }^{11}$ Departamento de Estatística, UFRGS; ${ }^{12}$ Hospital do Câncer A.C. Camargo, São Paulo, SP Brasil; ${ }^{13}$ Unidade de Análises Moleculares e de Proteínas, HCPA.

* Grupo de Estudos de Câncer de Mama e Câncer Colorretal. Hereditários: Jamile Abud ${ }^{1,2}$; Patrícia Koehler-Santos²; Patricia Ashton-Prolla ${ }^{2,3,4,5,6 ;}$ João Carlos Prolla ${ }^{1,7}$; Cristina Rossi $^{2,8}$; Edenir Inez Palmero9; Fernando Regla Vargas ${ }^{10}$; Luciana Neves Nunes ${ }^{11}$; Maria Izabel Achatz ${ }^{12}$; Miguel Ângelo Moreira ${ }^{10}$; Patrícia Izetti ${ }^{2,}$ 13; Silvia Liliana Cossio $2,6$. Correspondence: Dr. Jamile Abud - Laboratório de Medicina Genômica - Centro de Pesquisa Experimental - Hospital de Clínicas de Porto Alegre - Rua Ramiro Barcelos, 2350 - 90035-903 - Porto Alegre, RS, Brazil. E-mail: jamile.abud.genetica@gmail.com
} 
in $18.2 \%$ of the families studied. Considering these results, the authors proposed a new phenotype associated to the CHEK2 $1100 \mathrm{delC}$ mutation called hereditary breast and colon cancer syndrome (HBCC, OMIM\#604373) (Figure 1). The majority of reports that associate germline CHEK2 mutations with HBCC syndrome, describe the 1100delC mutation. However, definition of CHEK2 1100delC as a high penetrance mutation is still controversial and the existence of $\mathrm{HBCC}$ as a true syndromic entity has been questioned by some authors ${ }^{(22,26)}$. In fact, limited data are available in the literature on true associations of germline CHEK2 mutations with the HBCC phenotype, and recent reports suggest that there may be significant geographic differences in mutation frequency. In this study, we describe the frequency of CHEK2 1100delC in Brazilian families with multiple cases of breast and colorectal cancer.

\begin{tabular}{|c|c|c|}
\hline $\begin{array}{l}\text { CHEK2 } \\
\text { mutations }\end{array}$ & $\begin{array}{c}\text { Clinical } \\
\text { syndromes and } \\
\text { related tumors }\end{array}$ & References \\
\hline 1-BP DEL, $1100 \mathrm{C}$ & $\begin{array}{l}\text { LFS, HBCC } \\
\text { BC, CRC, } \\
\text { Prostate }\end{array}$ & $\begin{array}{l}\text { Bell et al. }{ }^{(3)} \\
\text { Vahteristo et al. }{ }^{(37,38)} \\
\text { Meijers-Heijboer } \\
\text { et al. }{ }^{(23,24)} \\
\text { Dong et al. }{ }^{(13)} \\
\text { CHEK2 Breast Cancer } \\
\text { Case-Control Consortium }{ }^{(6)} \\
\text { de Bock et al. }{ }^{(12)} \\
\text { Johnson et al. }{ }^{(16)} \\
\text { Cybulski et al. } .^{(10)}\end{array}$ \\
\hline Ile157Thr & $\begin{array}{l}\text { LFS } \\
\text { CRC, Prostate } \\
\text { and other tumors }\end{array}$ & $\begin{array}{l}\text { Bell et al. }{ }^{(3)} \\
\text { Dong et al. }{ }^{(13)} \\
\text { Kilpivaara et al. }{ }^{(17,18)} \\
\text { Cybulski et al. }{ }^{(10)}\end{array}$ \\
\hline $\operatorname{Arg} 145 \operatorname{Trp}$ & LFS & Lee et al. ${ }^{(20)}$ \\
\hline 1-BP DEL, $1422 \mathrm{~T}$ & LFS & Bell et al. ${ }^{(3)}$ \\
\hline 5.4-KB DEL & BC, Prostate & $\begin{array}{l}\text { Walsh et al. } .^{(40)} \\
\text { Cybulski et al. }{ }^{(10)}\end{array}$ \\
\hline IVS2DS, G-A, +1 & $\begin{array}{l}\text { Prostate and } \\
\text { other tumors }\end{array}$ & Cybulski et al. ${ }^{(10)}$ \\
\hline Ser428Phe & $\mathrm{BC}$ & Shaag et al. ${ }^{(33)}$ \\
\hline
\end{tabular}

LFS = Li-Fraumeni syndrome;

HBCC = hereditary breast and colon cancer;

$\mathrm{BC}=$ breast cancer

$\mathrm{CRC}=$ colorectal cancer

FIGURE 1. CHEK2 mutations and related phenotypes

\section{METHODS}

\section{Patient recruitment}

A total of 112 families with multiple diagnoses of breast and colorectal cancer fulfilling HBCC criteria $^{(24,26)}$ were recruited from cancer genetics clinics located in three Brazilian capitals: Rio de Janeiro (Instituto Nacional do Câncer, INCA), São Paulo (Hospital A. C. Camargo, HCACC) and Porto Alegre (Hospital de Clínicas de Porto Alegre, HCPA) between March 2007 and October 2008. In addition, families with multiple diagnoses of breast and colorectal cancer (at least three diagnosis and at least one patient under the age of 50 years), but not fulfilling the HBCC criteria described above, were also included (Figure 2). Of the 112 families interviewed, 59 unrelated index cases had their personal and family histories of cancer confirmed by medical records, pathology reports and/or death certificates, and agreed to participate in the study, providing clinical data and biological samples after informed consent. Clinical data were obtained from review of medical records and from patient interviews by a clinical geneticist. Medical and family histories $(\mathrm{FH})$ were recorded in detailed pedigrees with information traced as far backwards and laterally as possible, by extending through both maternal and paternal lines and including a minimum of three generations. Confirmation of cancer in the FH was attempted in all cases and pathology reports, medical records and/or death certificates were obtained whenever possible for relatives. Detailed information on tumor type, diagnosis and treatment were obtained for all index cases. All pedigrees were classified according to the clinical phenotypes that were observed. In addition to previously described criteria for the diagnosis of $\mathrm{HBCC}^{(24,26)}$, families were also reviewed for the presence of criteria for other cancer predisposition syndromes: HBOC (ASCO, NCCN), LFS/LFL (Classic, Birch, Eeles and Chompret) ${ }^{(4,7,8,11,14,21,27,29,35,36)}$ and Lynch Syndrome (Amsterdam criteria and Bethesda guidelines) ${ }^{(5,39)}$. All pedigrees and phenotypic criteria attributions were reviewed independently

\section{Meijers-Heijboer ${ }^{(25)}$}

At least two patients with breast cancer who were first- or seconddegree relatives and of whom at least one is diagnosed before age 60 years and

1. At least one patient with breast cancer and colorectal cancer diagnosed at any age; or

2. At least one individual with colorectal cancer diagnosed before age 50 years who was a first- or second degree relative of a patient with breast cancer; or

3. At least two patients with colorectal cancer diagnosed at any age of whom at least one was a first or second-degree relative of a patient with breast cancer.

Naseem $^{(27)}$

1. At least one patient with breast cancer and colorectal cance diagnosed at any age, and an additional case of $\mathrm{BC}$ or $\mathrm{CRC}$ in a first- or a second-degree relative,

2. At least one individual with CRC diagnosed before the age of 50 years who was a first- or second-degree relative of a patient with $\mathrm{BC}$, and the $\mathrm{BC}$ was 50 or there were at least two BCs in first- or second-degree relatives; or

3. At least two patients with CRC diagnosed at any age, of whom at least one was a first- or second-degree relative of a patient with $\mathrm{BC}$ and the $\mathrm{BC}$ was 50 or there were at least two BCs in first- or second-degree relatives.

Suggestive HBCC (in the present study)

1. At least one patient with breast cancer and an additional two cases of colorectal cancer at any age; or

2. At least one patient with colorectal cancer and an additional two cases of breast cancer at any age.

FIGURE 2. Clinical criteria defining HBCC syndrome 
by two clinical geneticists. The study was approved by the local ethics committees in all three participating institutions.

\section{Genotyping}

DNA was extracted from peripheral blood using the Ilustra blood genomicPrep Mini Spin kit (GE Healthcare, Buckinghamshire, UK). Samples were submitted to PCR amplification using a long-range PCR methodology as described by Sodha et al. ${ }^{(34)}$. Amplified products were submitted to sequencing in an ABI 3730 automated sequencer using the Big Dye Terminator v3.1 Cycle Sequencing Kit (Applied Biosystems, Foster City, USA) as described by the manufacturer. All analyses were performed in duplicates.

\section{Statistical analysis}

SPSS version 16.0 was used for data handling and statistical analyses. For descriptive analysis, categorical variables were described by their absolute and/or relative frequencies and quantitative variables were expressed as mean and standard deviation (SD).

\section{RESULTS}

Clinical data of the 59 unrelated patients included are summarized in Table 1. The mean age at recruitment was 48.5 years and the majority of probands were affected with breast cancer $(69.6 \%)$. The average prior probability of

TABLE 1. Demographic and clinical features of the sample studied $(\mathrm{n}=59)$

\begin{tabular}{|c|c|c|c|c|}
\hline Features & $\mathrm{n}$ & $\%$ & Mean (range) & SD \\
\hline \multicolumn{5}{|l|}{ Proband } \\
\hline \multicolumn{5}{|l|}{ Sex } \\
\hline Female & 53 & 89.8 & - & - \\
\hline \multicolumn{5}{|l|}{ Origin } \\
\hline RS & 28 & 47.5 & - & - \\
\hline SP & 14 & 23.7 & - & - \\
\hline $\mathrm{RJ}$ & 17 & 28.8 & - & - \\
\hline Cancer type & & & & - \\
\hline $\mathrm{BC}$ & 29 & 49.2 & - & - \\
\hline CRC & 12 & 20.3 & - & - \\
\hline Multiple* & 15 & 25.5 & - & - \\
\hline Other** & 3 & 5.1 & - & - \\
\hline Age of cancer onset & - & - & $48.5(29-75)$ & 10.90 \\
\hline \multicolumn{5}{|l|}{ Family } \\
\hline \multicolumn{5}{|l|}{ Cancer diagnoses } \\
\hline Number of cancer-affected generations & - & - & 2.8 & - \\
\hline Number of CRC cancers & - & - & 1.8 & - \\
\hline Number of Breast cancers & - & - & 3.1 & - \\
\hline Total CRC + BC per family & - & - & 4.8 & - \\
\hline \multicolumn{5}{|l|}{ Criteria } \\
\hline Meijer-Heijboer et al. ${ }^{(23)}$ & 16 & 27.1 & - & - \\
\hline Naseem et al. ${ }^{(26)}$ & 28 & 47.5 & - & - \\
\hline Suggestive & 29 & 49.2 & - & - \\
\hline $\begin{array}{l}\text { Criteria for other cancer } \\
\text { predisposition syndromes }\end{array}$ & 53 & 88.3 & - & - \\
\hline \multicolumn{5}{|l|}{ Lynch } \\
\hline Amsterdam & 7 & 11.9 & - & - \\
\hline Bethesda & 23 & 39.0 & - & - \\
\hline \multicolumn{5}{|l|}{ HBOC } \\
\hline ASCO & 22 & 37.3 & - & - \\
\hline NCCN & 25 & 42.4 & - & - \\
\hline \multicolumn{5}{|l|}{ LFS/LFL } \\
\hline Classic & 0 & - & - & - \\
\hline Chompret & 4 & 6.8 & - & - \\
\hline LFL $* * *$ & 29 & 49.2 & - & - \\
\hline $\begin{array}{l}* \mathrm{BC}(\mathrm{n}=5), \mathrm{CRC}+\mathrm{BC}(\mathrm{n}=5), \mathrm{CRC}+\text { other }(\mathrm{n}=3), \mathrm{BC}+\text { other }(\mathrm{n}=2) \\
* * \text { Other cancer: one thyroid, one ovary and one endometrium } \\
* * * \text { LFL included Birch }(\mathrm{n}=3,5.1 \%) \text { and Eeles }(\mathrm{n}=26,44.1 \%) \text { criteria }\end{array}$ & & $\begin{array}{l}\text { Rio Gra } \\
\text { ary breas } \\
\text { ni syndrc } \\
\text { ilike }\end{array}$ & $\begin{array}{l}\text { razil; SP, São Paulo - } \\
\text { ncer; }\end{array}$ & de Janei \\
\hline
\end{tabular}


being a carrier of a BRCA mutation in the overall sample was $16.0 \%$ and $16.4 \%$ using the mutation prevalence tables (Myriad) and the Penn II model (Penn II), respectively. The overall probability of carrying a BRCA mutation among breast cancer-affected probands $(n=41)$ was $20 \%$ and $18.2 \%$ using these two models, respectively. The prior probability of being a germline MMR mutation carrier ( $M L H 1$ and $M S H 2$ genes) using the Premm 1.2 Model (Premm 1.2) was $7.3 \%$ in the overall sample and $13.8 \%$ among CRC affected probands.

CHEK2 1100delC mutation was identified in one of the $59(1.7 \%)$ individuals studied. At recruitment, the patient was a 61 year-old woman diagnosed with breast cancer at the age of 52 years, and her family matched clinical criteria for HBCC according to Meijers-Heijboer et al. ${ }^{(24)}$ and Naseem et al. ${ }^{(26)}$ and none of the other criteria for hereditary breast and colorectal cancer syndromes that were considered in this study (Figure 3). The proband's breast tumor was an invasive ductal carcinoma, showing HER-2/neu oncoprotein overexpression, positive staining for progesterone receptor and negative staining for estrogen receptor.

\section{DISCUSSION}

A recurrent mutation in the CHEK2 gene (1100delC) was first reported to be an important cause of breast cancer by Meijers-Heijboer et al. ${ }^{(23)}$. Since then, numerous studies have documented the prevalence of this single mutation in breast cancer-affected women from different countries. In a recent meta-analysis study, Weischer et al. ${ }^{(42)}$ conclude that CHEK2 1100delC is an important breast cancer-predisposing mutation, which increases cancer risk by three-to five-fold in its carriers. In 2008, Wasielewski et al. ${ }^{(41)}$, found a frequency of $4.2 \%$ of CHEK2 1100 delC mutation in 237 patients diagnosed with Lynch syndrome, compared with a frequency of $1.0 \%$ in population controls, suggesting a strong association of this specific mutation with familial colorectal cancer $(P=0.002)$.

In the present study, we assessed the CHEK2 1100delC mutation among families with multiple breast and colorectal cancer diagnoses, and we encountered only one carrier proband, which is significantly less than expected from the original report by Meijers-Heijboer et al. ${ }^{(24)}$ in families with

A

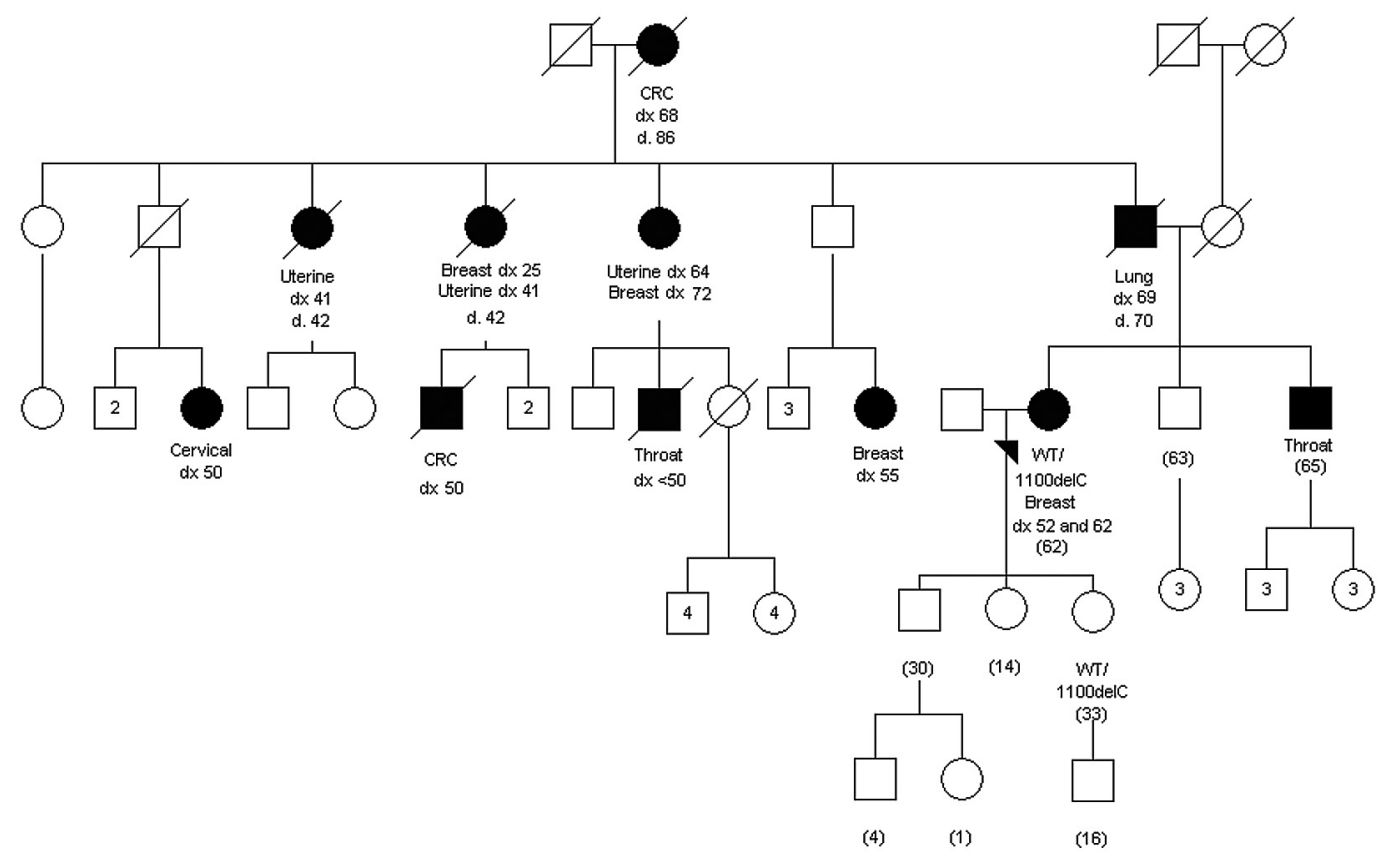

B

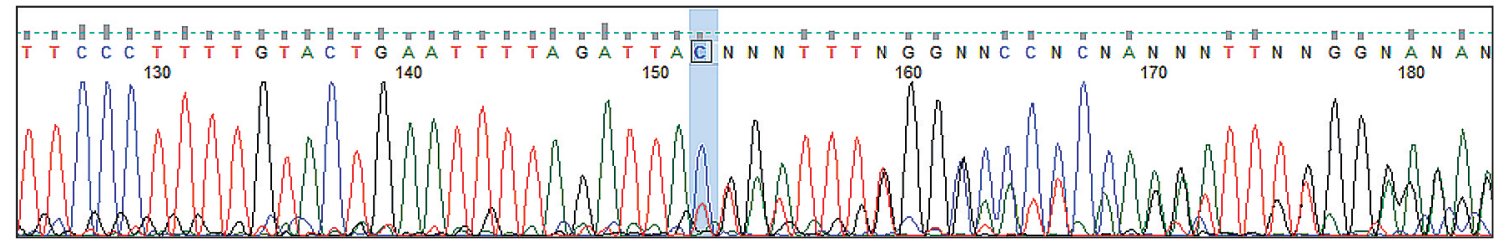

FIGURE 3. A. Pedigree of the patient identified as CHEK2 1100delC mutation carrier. Cancer-affected individuals are shown in blackened symbols. Arrowhead indicates proband; current age is indicated in parenthesis. Dx: age at diagnosis; d: age at death; wt: wild-type. B. Proband's electropherogram: direct sequencing of CHEK2 exon 10 indicating frameshift after the $1100 \mathrm{C}$ position 
similar cancer histories. However, other mutation prevalence studies among $\mathrm{HBCC}$ families in different countries point to a frequency of CHEK2 1100 delC below $5 \%$ among $\mathrm{HBCC}$ families, including studies in Sweden, Spain and the United Kingdom ${ }^{(15,26,31)}$. Thus, in the Netherlands, the CHEK2 1100delC mutation appears to be unusually frequent, and this is reflected in the finding that $4 \%$ of women with early onset breast cancer (irrespective of CRC history in the family) carry CHEK2 1100 delC in that country. In other Northern European countries, the frequency of the mutation among early-onset $\mathrm{BC}$ patients appears to be lower (2.3\% in Germany and $2.5 \%$ in Finland). Finally, in other countries, such as Spain and Australia, the mutation has been reported at a very low frequency ${ }^{(25)}$. Based on these data, the worldwide distribution of the CHEK2 1100delC mutation is clearly heterogeneous and its frequency in different countries should be known before mutation screening initiatives are considered. We conclude that in Brazilian families, recruited from the Southern and Southeastern regions of the country and with a strong family history of breast and colorectal cancer, CHEK2 1100delC is not frequent. Further investigations of other CHEK2 mutations and/or mutations in other cancer predisposition genes are being undertaken in these families.

\section{ACKNOWLEDGMENTS}

We are indebted to the patients and their family members who agreed to participate in this study and to Fundação de Incentivo à Pesquisa do Hospital de Clínicas de Porto Alegre (FIPe-HCPA) and Programa de Pós-Graduação em Ciências Gastroenterológicas (UFRGS) who provided funding for this study. We thank Amanda de Nobrega, RN for help with patient recruitment.

Abud J, Koehler-Santos P, Ashton-Prolla P, Prolla JC; Grupo de Estudos de Câncer de Mama e Câncer Colorretal Hereditários. Mutação germinativa 1100delC no gene CHEK2: estudo da frequência em famílias brasileiras com câncer de mama e cólon hereditários. Arq Gastroenterol. 2012;49(4):273-8.

RESUMO - Introdução - CHEK2 codifica uma proteína quinase envolvida em um ponto de checagem do ciclo celular que desempenha um papel importante na via de reparação do DNA, danos ativados principalmente por ATM (Ataxia Telangiectasia Mutado) em resposta a danos na dupla hélice do DNA. A mutação germinativa 1100delC no gene CHEK2 tem sido descrita como um alelo de baixa penetrância em um número significativo de famílias com câncer de mama e cólon em certos países e também está associada com risco aumentado de câncer de mama contralateral em mulheres previamente afetadas pela doença. Cerca de 5\%-10\% de todos os cânceres de mama e colorretais estão associados a predisposição hereditária e o seu reconhecimento é de grande importância para o aconselhamento genético e gestão do risco de câncer. Objetivos - Neste estudo foi avaliada a frequência da mutação germinativa 1100delC no gene CHEK2 em 59 diferentes indivíduos brasileiros com critérios clínicos para a síndrome de câncer de mama e cólon hereditários. Método - Utilizamos como estratégia a realização do PCR de longo alcance seguido de sequenciamento. Resultados - A mutação 1100delC foi encontrada em um indivíduo (1,7\%), indicando que esta mutação germinativa não é comumente encontrada em famílias brasileiras com múltiplos diagnósticos de câncer de mama e câncer colorretal. Conclusão - Estes resultados devem ser confirmados em uma série maior de famílias, e estudos adicionais devem ser realizados para investigar a patologia molecular do fenótipo HBCC.

DESCRITORES - Neoplasias da mama, genética Neoplasias do colo, genética. Proteínas serina-treonina quinases. Predisposição genética para doença.

\section{REFERENCES}

1. Allain DC. Genetic counseling and testing for common hereditary breast cancer syndromes: a paper from the 2007 William Beaumont hospital symposium on molecular pathology. J Mol Diagn. 2008;10:383-95.

2. Antoni L, Sodha N, Collins I, Garrett M. CHK2 kinase: cancer susceptibility and cancer therapy - two sides of the same coin? Nat Rev Cancer. 2007;7:925-36.

3. Bell DW, Varley JM, Szydlo TE, Kang DH, Wahrer DC, Shannon KE, Lubratovich M, Verselis SJ, Isselbacher KJ, Fraumeni JF, Birch JM, Li FP, Garber JE, Haber DA. Heterozygous germ line hCHK2 mutations in Li-Fraumeni syndrome. Science. 1999;286:2528-31.

4. Birch JM, Hartley AL, Tricker KJ, Prosser J, Condie A, Kelsey AM, Harris M, Jones PH, Binchy A, Crowther D, et al. Prevalence and diversity of constitutional mutations in the p53 gene among 21 Li-Fraumeni families. Cancer Res. 1994:54:1298-304.

5. Boland CR, Thibodeau SN, Hamilton SR, Sidransky D, Eshleman JR, Burt RW, Meltzer SJ, Rodriguez-Bigas MA, Fodde R, Ranzani GN, Srivastava S. A National Cancer Institute Workshop on Microsatellite Instability for cancer detection and familial predisposition: development of international criteria for the determination of microsatellite instability in colorectal cancer. Cancer Res. 1998;58:5248-57.

6. The CHEK2 - Breast Cancer Case-Control Consortium CHEK2*1100delC and susceptibility to breast cancer: a collaborative analysis involving 10,860 breast cases and 9,065 controls from 10 studies. Am J Hum Genet. 2004;74:1175-82.

7. Chompret A, Brugières L, Ronsin M, Gardes M, Dessarps-Freichey F, Abel A, Hua D, Ligot L, Dondon M, Bressac-de Paillerets B, Frébourg T, Lemerle J, Bonaïti-Pellié C, Feunteun J. p53 germline mutations in childhood cancers and cancer risk for carrier individuals. Br J Cancer. 2000;82:1932-7.
8. Chompret A, Abel A, Stoppa-Lyonnet D, Brugiéres L, Pagés S, Feunteun J, Bonaïti-Pellié C. Sensitivity and predictive value of criteria for p53 germline mutation screening. J Med Genet. 2001;38:43-7.

9. Cybulski C, Górski B, Huzarski T, Masojć B, Mierzejewski M, Debniak T, Teodorczyk U, Byrski T, Gronwald J, Matyjasik J, Zlowocka E, Lenner M, Grabowska E, Nej K, Castaneda J, Medrek K, Szymańska A, Szymańska J, Kurzawski G, Suchy J, Oszurek O, Witek A, Narod S, Lubiński J. CHEK2 is a multiorgan cancer susceptibility gene. Am J Hum Genet. 2004;75:1131-5.

10. Cybulski C, Wokołorczyk D, Huzarski T, Byrski T, Gronwald J, Górski B, Debniak T, Masojń B, Jakubowska A, Gliniewicz B, Sikorski A, Stawicka M, Godlewski D, Kwias Z, Antczak A, Krajka K, Lauer W, Sosnowski M, Sikorska-Radek P, Bar K, Klijer R, Zdrojowy R, Małkiewicz B, Borkowski A, Borkowski T, Szwiec M, Narod SA, Lubiński J. A large germline deletion in the Chek2 kinase gene is associated with an increased risk of prostate cancer. J Med Genet. 2006;43:863-6.

11. Dana-Faber Cancer Institute. Lynch syndrome (hereditary nonpolyposis colorectal cancer. PREMM1,2,6 model: prediction model for MLH1, MSH2, and MSH6 gene mutations. Available from: http://dana-farber.prod.dfcidev.org/pat/cancer/ gastrointestinal/crc-calculator/default.asp

12. de Bock GH, Schutte M, Krol-Warmerdam EMM, Seynaeve C, Blom J, Brekelmans CTM, Meijers-Heijboer H, van Asperen CJ, Cornelisse CJ, Devilee $\mathrm{P}$, Tollenaar RA, Klijn JG. Tumour characteristics and prognosis of breast cancer patients carrying the germline CHEK $2 * 1100 \mathrm{delC}$ variant. J Med Genet. 2004:41:731-5.

13. Dong X, Wang L, Taniguchi K, Wang X, Cunningham JM, McDonnell SK, Qian C, Marks AF, Slager SL, Peterson BJ, Smith DI, Cheville JC, Blute ML, Jacobsen SJ, Schaid DJ, Tindall DJ, Thibodeau SN, Liu W. Mutations in CHEK2 associated with prostate cancer risk. Am J Hum Genet. 2003;72:270-80. 
14. Frank TS, Deffenbaugh AM, Reid JE, Hulick M, Ward BE, Lingenfelter B, Gumpper KL, Scholl T, Tavtigian SV, Pruss DR, Critchfield GC. Clinical characteristics of individuals with germline mutations in BRCA1 and BRCA2: analysis of 10,000 individuals. J Clin Oncol. 2002;20:1480-90

15. Isinger A, Bhat $\mathrm{M}$, Borg A, Nilbert M. CHEK2 1100 delC in patients with metachronous cancers of the breast and the colorectum. BMC Cancer. 2006;6:64.

16. Johnson N, Fletcher O, Naceur-Lombardelli C, dos Santos Silva I, Ashworth A, Peto J. Interaction between CHEK $2 * 1100$ delC and other low-penetrance breast-cancer susceptibility genes: a familial study. Lancet. 2005;366:1554-7.

17. Kilpivaara O, Vahteristo P, Falck J, Syrjäkoski K, Eerola H, Easton D, Bartkova J, Lukas J, Heikkilä P, Aittomäki K, Holli K, Blomqvist C, Kallioniemi OP, Bartek J, Nevanlinna H. CHEK2 variant I157T may be associated with increased breast cancer risk. Int J Cancer. 2004;111:543-7.

18. Kilpivaara O, Alhopuro P, Vahteristo P, Aaltonen LA, Nevanlinna, H. CHEK2 I157T associates with familial and sporadic colorectal cancer. J Med Genet. 2006;43:e34.

19. Koppert LB, Schutte M, Abbou M, Tilanus H, Dinjens WN. The CHEK$2(*) 1100$ delC mutation has no major contribution in oesophageal carcinogenesis. Br J Cancer. 2004;90:888-91.

20. Lee SB, Kim SH, Bell DW, Wahrer DC, Schiripo TA, Jorczak MM, Sgroi DC, Garber JE, Li FP, Nichols KE, Varley JM, Godwin AK, Shannon KM, Harlow E, Haber DA. Destabilization of CHK2 by a missense mutation associated with Li-Fraumeni syndrome. Cancer Res. 2001;61:8062-7.

21. Li FP, Fraumeni JF Jr, Mulvihill JJ, Blattner WA, Dreyfus MG, Tucker MA Miller RW. A cancer family syndrome in twenty-four kindreds. Cancer Res. 1988;48:5358-62.

22. Lipton L, Thomas HJ, Eeles RA, Houlston RS, Longmuir M, Davison R, Hodgson SV, Murday VA, Norbury CG, Taylor C, Tomlinson IP. Apparent Mendelian inheritance of breast and colorectal cancer: chance, genetic heterogeneity or a new gene? Fam Cancer. 2001;1:189-95.

23. Meijers-Heijboer H, van den Ouweland A, Klijn J, Wasielewski M, de Snoo A, Oldenburg R, Hollestelle A, Houben M, Crepin E, van Veghel-Plandsoen M, Elstrodt F, van Duijn C, Bartels C, Meijers C, Schutte M, McGuffog L, Thompson D, Easton D, Sodha N, Seal S, Barfoot R, Mangion J, Chang-Claude J, Eccles D, Eeles R, Evans DG, Houlston R, Murday V, Narod S, Peretz T, Peto J, Phelan C, Zhang HX, Szabo C, Devilee P, Goldgar D, Futreal PA, Nathanson KL, Weber B, Rahman N, Stratton MR; CHEK2-Breast Cancer Consortium. Low-penetrance susceptibility to breast cancer due to CHEK2 $\left(^{*}\right) 1100$ delC in noncarriers of BRCA1 or BRCA2 mutations. Nature Genet. 2002;31:55-9.

24. Meijers-Heijboer H, Wijnen J, Vasen H, Wasielewski M, Wagner A, Hollestelle A, Elstrodt F, van den Bos R, de Snoo A, Fat GT, Brekelmans C, Jagmohan S, Franken P, Verkuijlen P, van den Ouweland A, Chapman P, Tops C, Möslein G, Burn J, Lynch H, Klijn J, Fodde R, Schutte M. The CHEK2 1100delC mutation identifies families with a hereditary breast and colorectal cancer phenotype. Am J Hum Genet. 2003;72:1308-14.

25. Meijers-Heijboer H, Wijnen J, Vasen H, Wasielewski M, Wagner A, Hollestelle A, Elstrodt F, van den Bos R, de Snoo A, Fat GT, Brekelmans C, Jagmohan S, Franken P, Verkuijlen P, van den Ouweland A, Chapman P, Tops C, Möslein G, Burn J, Lynch H, Klijn J, Fodde R, Schutte M. The CHEK2 1100delC mutation identifies families with a hereditary breast and colorectal cancer phenotype. Am J Hum Genet. 2003;72:1308-14.

26. Narod S, Lynch H. CHEK2 mutation and hereditary breast cancer. J Clin Oncol 2007;25:6-7.

27. Naseem H, Boylan J, Speake D, Leask K, Shenton A, Lalloo F, Hill J, Trump D, Evans DG. Inherited association of breast and colorectal cancer: limited role of CHEK2 compared with high-penetrance genes. Clin Genet. 2006;70:388-95.
28. National Comprehensive Cancer Network-NCCN. Practice guidelines for detection, prevention, \& risk reduction. Genetic/familial high-risk assessment: breast and ovarian [Internet]. 2010. Available from: http://www.ncen.org/professionals/ physician_gls/f_guidelines.asp\#genetic_screening.

29. Nevanlinna H, Bartek J. The CHEK2 gene and inherited breast cancer susceptibility. Oncogene. 2006;25:5912-9.

30. Olivier M, Goldgar D, Sodha N, Ohgaki H, Kleihues P, Hainaut P, Eeles R. Li-Fraumeni and related syndromes: correlation between tumor type, family structure, and TP53 genotype. Cancer Res. 2003;63:6643-50.

31. Ruijs MW, Broeks A, Menko FH, Ausems MG, Wagner A, Oldenburg R, Meijers-Heijboer H, van't Veer LJ, Verhoef S. The contribution of CHEK2 to the TP53-negative Li-Fraumeni phenotype. Hered Cancer Clin Pract. 2009;7:4

32. Sánchez de Abajo A, de la Hoya M, Godino J, Furió V, Tosar A, Pérez-Segura P, Díaz-Rubio E, Caldés T. The CHEK2 1100delC allele is not relevant for risk assessment in HNPCC and HBCC Spanish families. Fam Cancer. 2005;4:183-6.

33. Schutte M, Seal S, Barfoot R, Meijers-Heijboer H, Wasielewski M, Evans DG, Eccles D, Meijers C, Lohman F, Klijn J, van den Ouweland A, Futreal PA, Nathanson KL, Weber BL, Easton DF, Stratton MR, Rahman N; Breast Cancer Linkage Consortium. Variants in CHEK2 other than 1100 delC do not make a major contribution to breast cancer susceptibility. Am J Hum Genet. 2003;72:1023-8.

34. Shaag A, Walsh T, Renbaum P, Kirchhoff T, Nafa K, Shiovitz S, Mandell JB, Welcsh P, Lee MK, Ellis N, Offit K, Levy-Lahad E, King MC. Functional and genomic approaches reveal an ancient CHEK2 allele associated with breast cancer in the Ashkenazi Jewish population. Hum Mol Genet. 2005;14:555-63.

35. Sodha N, Houlston RS, Williams R, Yuille MA, Mangion J, Eeles RA. A roubust method for detecting CHK2/RAD53 mutation in genomic DNA. Human Mutation. 2002;19:173-7.

36. Statement of the American Society of Clinical Oncology: genetic testing for cancer susceptibility, adopted on February 20, 1996. J Clin Oncol. 1996;14:1730-6.

37. University of Pennsylvania. Abramson Cancer Center. Couch modifies mutation prediction model [Internet]. 2011. Available from: http://www.afcri.upenn.edu/ itacc/penn $2 /$

38. Vahteristo P, Tamminen A, Karvinen P, Eerola H, Eklund C, Aaltonen LA, Blomqvist C, Aittomäki K, Nevanlinna H. p53, CHK2, and CHK1 genes in families with Li-Fraumeni syndrome: further evidence of $\mathrm{CHK} 2$ in inherited cancer predisposition. Cancer Res. 2001;61:5718-22.

39. Vahteristo P, Bartkova J, Eerola H, Syrjäkoski K, Ojala S, Kilpivaara O, Tamminen A, Kononen J, Aittomäki K, Heikkilä P, Holli K, Blomqvist C, Bartek J, Kallioniemi OP, Nevanlinna H. A CHEK2 genetic variant contributing to a substantial fraction of familial breast cancer. Am J Hum Genet. 2002;71:432-8.

40. Vasen HF. Clinical description of the Lynch syndrome [hereditary nonpolyposis colorectal cancer (HNPCC)]. Fam Cancer. 2005;4:219-25.

41. Walsh T, Casadei S, Coats KH, Swisher E, Stray SM, Higgins J, Roach KC, Mandell J, Lee MK, Ciernikova S, Foretova L, Soucek P, King MC. Spectrum of mutations in BRCA1, BRCA2, CHEK2, and TP53 in families at high risk of breast cancer. JAMA. 2006;295:1379-88.

42. Wasielewski M, Vasen H, Wijnen J, Hooning M, Dooijes D, Tops C, Klin JGM, Meijers-Heijboer H, Schutte M. CHEK2 1100 delC is a susceptibility allele for HNPCC-related colorretal cancer. Clin Cancer Res. 2008;14:4989-94.

43. Weischer M, Bojesen SE, Ellervik C, Tybjaerg-Hansen A, Nordestgaard BG. CHEK$2 * 1100$ delC genotyping for clinical assessment of breast cancer risk: meta-analyses of 26,000 patient cases and 27,000 controls. J Clin Oncol. 2008;26:542-8.

Received 16/8/2012 Accepted 12/9/2012

\section{ERRATUM}

In article "CHEK2 1100DELC germline mutation: a frequency study in hereditary breast and colon cancer Brazilian families" published in journal Arquivos de Gastroenterologia, v.49(4):273-8, on page 273 which was read:

Jamile ABUD ${ }^{1}$, João Carlos PROLLA ${ }^{\mathbf{1}, \mathbf{2}}$ and The Study Group on Hereditary Breast and Colorectal Cancer*

read:

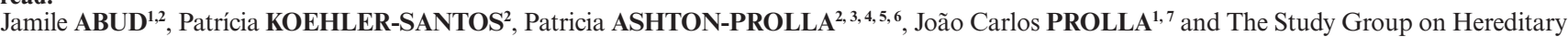
Breast and Colorectal Cancer*

which was read:

* Grupo de Estudos de Câncer de Mama e Câncer Colorretal Hereditários: Jamile Abud ${ }^{1}$; João Carlos Prolla ${ }^{1,2}$; Cristina Rossi ${ }^{3,4}$; Edenir Inez

Palmero 5 ; Fernando Regla Vargas ${ }^{6}$; Luciana Neves Nunes ${ }^{7}$; Maria Izabel Achatz ${ }^{8}$; Miguel Ângelo Moreira ${ }^{6}$; Patricia Ashton-Prolla ${ }^{4,9,10,11,12 .}$ Patrícia Izetti ${ }^{4,13}$; Silvia Liliana Cossio ${ }^{4,12}$.

read:

* Grupo de Estudos de Câncer de Mama e Câncer Colorretal. Hereditários: Jamile Abud ${ }^{1,2}$; Patrícia Koehler-Santos²; Patricia Ashton-Prolla ${ }^{2,3,4,5,6 \text {; }}$ João Carlos Prolla ${ }^{1,7}$; Cristina Rossi ${ }^{2,8}$; Edenir Inez Palmero'; Fernando Regla Vargas ${ }^{10}$; Luciana Neves Nunes ${ }^{11}$; Maria Izabel Achatz ${ }^{12}$; Miguel Ângelo Moreira ${ }^{10}$; Patrícia Izetti ${ }^{2,13}$; Silvia Liliana Cossio ${ }^{2,6}$. 